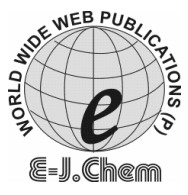

\|\|$\|$

ISSN: 0973-4945; CODEN ECJHAO

E-Journal of Chemistry

http://www.e-journals.net

Vol. 5, No.3, pp. 598-606, July 2008

\title{
Kinetics and Mechanistic Study of Cetyltrimethylammonium Bromide Catalyzed Oxidation of Tetraethylene Glycol by $N$-Chlorosaccharin in Acidic Medium
}

\author{
VANDANA SHARMA $^{\S *}$, K. V. SHARMA ${ }^{\S}$ and V. W. BHAGWAT ${ }^{\#}$ \\ ${ }^{\S}$ Mahakal Institute of Technology, Ujjain 456010, India. \\ ${ }^{\#}$ School of Studies in Chemistry, Vikram University, Ujjain 456010, India. \\ vandanak_sharma@yahoo.co.in
}

Received 7 December 2007; Accepted 5 January 2008

\begin{abstract}
The kinetics and mechanism of cetyltrimethylammonium bromide catalyzed oxidation of tetraethylene glycol [2,2-(oxibis(ethylenoxy)diethanol)] by $N$-chlorosaccharin in aqueous acetic acid medium in presence of perchloric acid have been investigated at $323 \mathrm{~K}$. The reaction is first order dependence on $N$ chlorosaccharin. The reaction rate follows first order kinetics with respect to [tetraethylene glycol] with excess concentration of other reactants. The miceller effect due to cetyltrimethylammonium bromide, a cationic surfactant has been studied. The change in ionic strength shows negligible salt effect. The dielectric effect is found to be positive. Addition of one of the products (saccharin) retards the reaction rate. Activation parameters are calculated from the Arrhenious plot. A possible mechanism consistent with the experimental results has been proposed.
\end{abstract}

Keywords: Tetraethylene glycol, $N$-chlorosaccharin, Kinetics, Mechanism, Micelle system

\section{Introduction}

Tetraethylene glycol, $\mathrm{HO}\left(\mathrm{C}_{2} \mathrm{H}_{4} \mathrm{O}\right)_{4} \mathrm{H}$, is a colourless, odourless, non-volatile, and hygroscopic liquid. It is characterized by two hydroxyl groups along with three ether linkages, which contribute to its high water solubility, hygroscopicity, solvent properties and reactivity with many organic compounds. Tetraethylene glycol (TrEG) possess higher boiling point and lower volatility than the lower ethylene glycols, it is completely miscible with water and a wide range of organic solvents, but has only slight affinity for certain aliphatic hydrocarbons. Tetraethylene glycol is especially useful in the preparation of polyester resins and as a plasticizer. TrEG is also used as chemical intermediate and as a solvent in the production of inks and dyes. TrEG is often used as a process solvent in hydrocarbon purification processes and as a coupling agent in the production of textile lubricants and formulations. Oxidation of polyethylene glycols, other alcohols and diols by different oxidants have been carried out by various workers ${ }^{1-11}$ but no one has ever used 
TrEG. The $\mathrm{N}$-chlorosaccharin $\left(\mathrm{C}_{6} \mathrm{H}_{4} \mathrm{COSO}_{2} \mathrm{NCl}\right)$ abbreviated, as (NCSA) is a versatile oxidant $^{12-16}$. The oxidation of TrEG by acidic $N$-chlorosaccharin is an extremely slow reaction. The reaction has found to be catalyzed by a cationic surfactant cetyltrimethylammonium bromide $\left(\mathrm{C}_{16} \mathrm{TAB}\right)$. Therefore, $\mathrm{C}_{16} \mathrm{TAB}$ catalyzed oxidation of TrEG by $N$-chlorosaccharin has been undertaken.

\section{Experimental}

Tetraethylene glycol (Merck) was used. $N$-chlorosaccharin was prepared by reported procedure ${ }^{13}$. Double-distilled water and purified acetic acid were used for the preparation of NCSA solution and standard solution of NCSA was prepared afresh. Sodium perchlorate (Merck) was used to keep the ionic strength constant. The other chemicals were of the Analytical grade and double-distilled water was used for preparation of solutions.

Requisite amount (appropriate volume of known concentration) of TrEG, perchloric acid, $\mathrm{C}_{16} \mathrm{TAB}$, water and other reagent solution were mixed into a reaction vessel. A separately thermostated solution of $N$-chlorosaccharin was added to commence the reaction. Residual amount of NCSA was determined iodometrically by using standard sodium thiosulphate solution. In all the experiments, the reactions were followed up to two half lives. A constant ionic strength of the reaction mixture was maintained by adding required amount of sodium perchlorate solution.

Product analysis and stoichiometry

TrEG (350 mg /250 mL water), perchloric acid (0.1M/ $100 \mathrm{~mL}), \mathrm{C}_{16} \mathrm{TAB}(12 \mathrm{mg} / 100 \mathrm{~mL})$ and NCSA $(10 \mathrm{~g} / 100 \mathrm{~mL})$ were mixed for product analysis. After a reaction time of 48 hour, the organic components were separated from the mixture into ether; the ethereal extract was dried and concentrated using rotatory evaporator, under low pressure. Using benzene, ethyl acetate mixture $8: 2(v / v)$ as an eluent, preliminary studies were carried out by thin layer chromatography. A distinct single spot was obtained. A solution of 2, 4-dinitrophenylhydrazine was added to it and then the reaction mixture was left overnight in the refrigerator at $5^{\circ} \mathrm{C}$ temperature. The solution was centrifuged and brown-orange residue is obtained. This formation of 2,4-DNP derivative adequately confirmed the oxidation product of the TrEG to be a [2,2-oxibis(ethylenoxy)(1hydroxy)octanal].The aldehyde was conformed by IR spectra which shows bands at $3450 \mathrm{~cm}^{-1}$ and $1620 \mathrm{~cm}^{-1}$ for $\mathrm{OH}$ stretching and $\mathrm{C}=\mathrm{O}$ Stretching respectively and a band at $2720 \mathrm{~cm}^{-1}$ for aldehydic C-H stretching. The fact that only one hydroxyl group was attacked and other remained intact gets support from stoichiometry of the reaction as well. Literature survey shows that similar types of oxidative products were reported ${ }^{27-30}$. Stoichiometry was determined by using varying ratios of the oxidant to TEG were thermostated at $25^{\circ} \mathrm{C}$ for $48 \mathrm{~h}$ incubation and residual NCSA was determined iodometrycally using standard sodium thiosulphate The mole ratio (number of moles of the oxidant consumed per mole of TrEG) was calculated. TrEG and $\mathrm{N}$ - chlorosaccharin reacts in 1:1 stoichiometry, as follows:

$$
\begin{aligned}
& \mathrm{OHCH}_{2}-\mathrm{CH}_{2}-\mathrm{O}-\mathrm{CH}_{2}-\mathrm{CH}_{2}-\mathrm{O}-\mathrm{CH}_{2}-\mathrm{CH}_{2}-\mathrm{O}-\mathrm{CH}_{2}-\mathrm{CH}_{2} \mathrm{OH}+\mathrm{C}_{6} \mathrm{H}_{4} \mathrm{COSO}_{2} \mathrm{NCl} \rightarrow \\
& \mathrm{OHCH}_{2}-\mathrm{CH}_{2}-\mathrm{O}-\mathrm{CH}_{2}-\mathrm{CH}_{2}-\mathrm{O}-\mathrm{CH}_{2}-\mathrm{CH}_{2}-\mathrm{O}-\mathrm{CH}_{2}-\mathrm{CHO}+\mathrm{C}_{6} \mathrm{H}_{4} \mathrm{COSO}_{2} \mathrm{NH}+\mathrm{HCl}
\end{aligned}
$$

\section{Results and Discussion}

\section{Order with respect to [N-chlorosaccharin]}

The order of the reaction with respect to the concentration of NCSA is determined by studying the rate of the reaction at different initial concentrations of the NCSA. The rate constants obtained at various initial concentrations of NCSA at constant concentration of 
$\left[\mathrm{H}^{+}\right] 0.05 \mathrm{~mol} \mathrm{dm}^{-3}$ and $\left.[\mathrm{TrEG}] 0.08 \mathrm{~mol} \mathrm{dm}^{-3}\right)$ are given in Table 1 . The plot of $\log (\mathrm{a}-\mathrm{x})$ versus time (Figure 1) gave a straight line, which indicates that reaction under the chosen conditions follows pseudo first order kinetics. The order with respect to NCSA is one. The mean pseudo first-order rate constant, $\mathrm{k}_{0}$ was found to be $(0.09 \pm 0.1) \times 10^{-5} \mathrm{~s}^{-1}$.

Table 1. Order with respect to $N$-chlorosaccharin $[\mathrm{TrEG}]=0.08$ mole dm$^{-3} ;\left[\mathrm{HClO}_{4}\right]=0.05 \mathrm{~mole} \mathrm{dm}^{-3}$; $\left[\mathrm{C}_{16} \mathrm{TAB}\right]=0.004$ mole $\mathrm{dm}^{-3}$; Temperature $323 \mathrm{~K}$

\begin{tabular}{cc}
\hline$[\mathrm{NCSA}] / 10^{-3} \mathrm{~mol} \mathrm{dm}^{-3}$ & $\mathrm{k}^{*} / 10^{-4} \mathrm{~s}^{-1}$ \\
\hline 2.5 & 8.84 \\
4.0 & 4.21 \\
5.0 & 3.39 \\
10.0 & 1.98 \\
15.0 & 1.22 \\
20.0 & 1.01 \\
\hline
\end{tabular}

* Mean of duplicate experiments

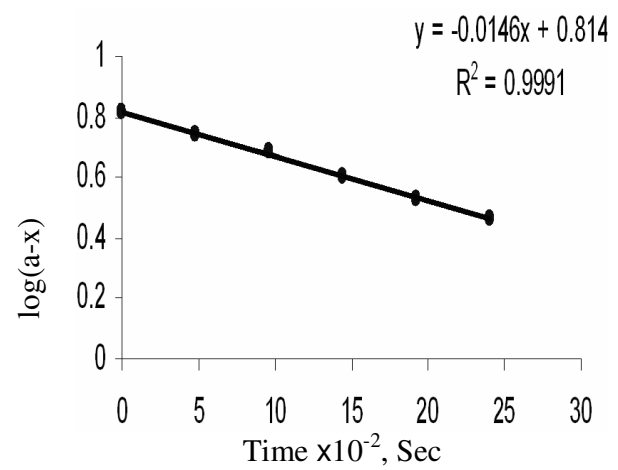

Figure 1. Dependence of rate on NCSA

\section{Order with respect to [TrEG]}

On varying TrEG concentration from $4.0 \times 10^{-2}$ to $24.0 \times 10^{-2} \mathrm{~mol} \mathrm{dm}{ }^{-3}$ there is an increase in rate of reaction (Table 2). The plots of $\log \mathrm{k}$ versus $\log [\mathrm{TrEG}]$ (Figure 2) gave straight line with slope equal to $0.88\left(\mathrm{R}^{2}=0.99\right)$, suggesting that order with respect to TrEG is one.

Table 2. Effect of tetraethylene glycol concentration variation.

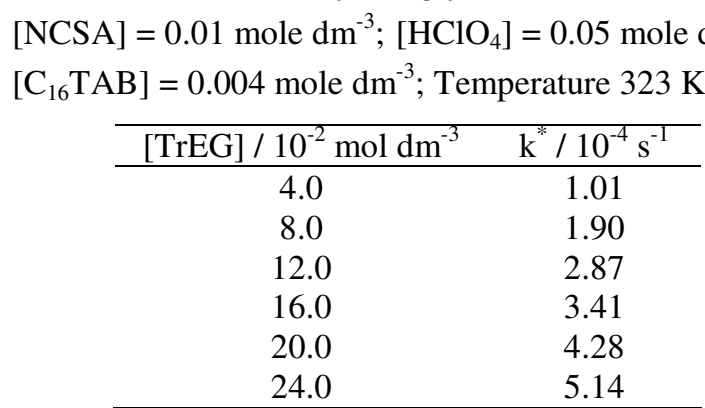

* Mean of duplicate experiments 


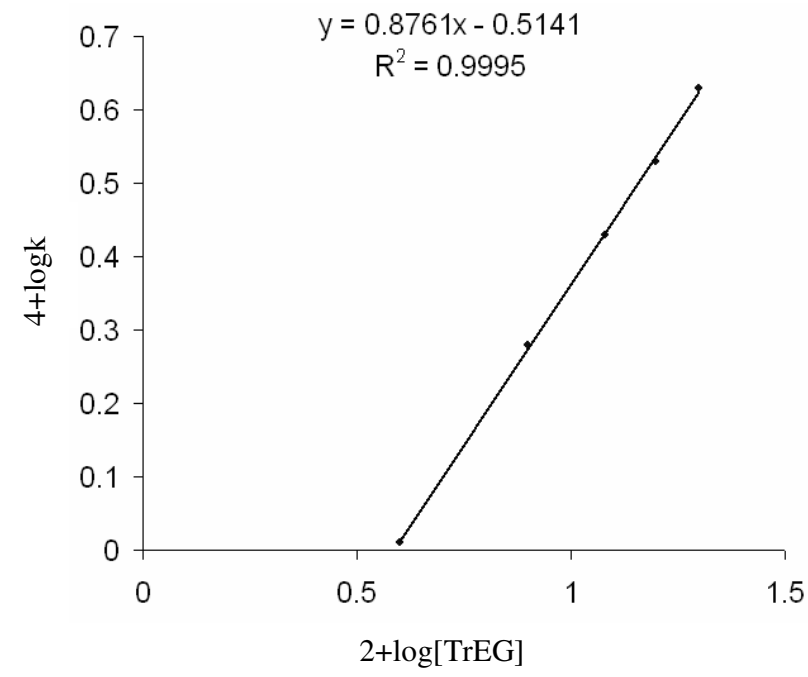

Figure 2. Order with respect to [TrEG]

A double reciprocal plot between $\mathrm{k}^{-1}$ versus $[\mathrm{TrEG}]^{-1}$ (Figure 3) has been found to be linear with positive intercept at $y$-axis. This kinetic evidence of complex formation between the substrate and the oxidant, further support the first order dependence.

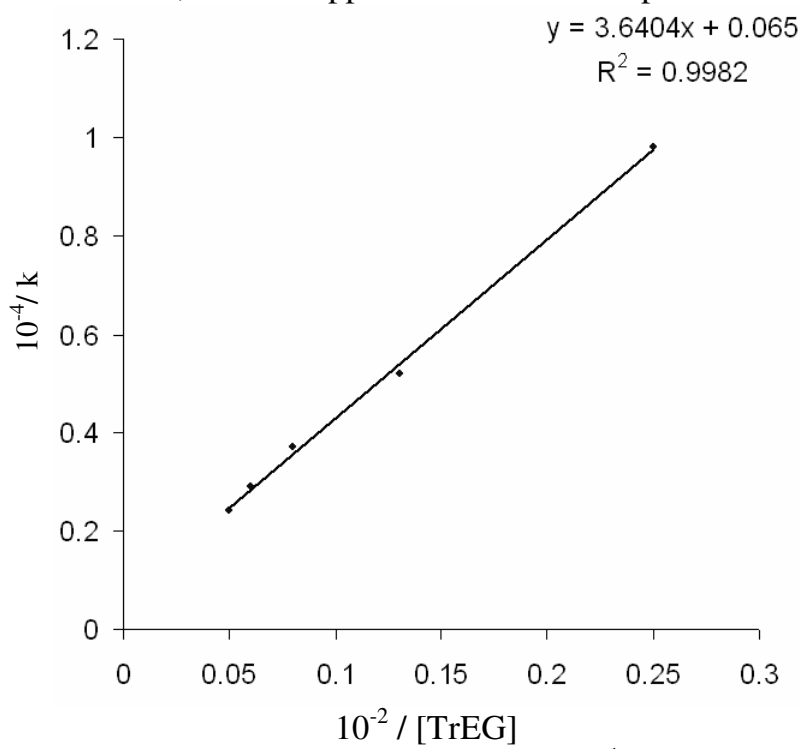

Figure 3. Double reciprocal plot between $\mathrm{k}^{-1}$ versus $[\mathrm{TrEG}]^{-1}$

\section{Effect of variation of $\left[\mathrm{H}^{+}\right]$}

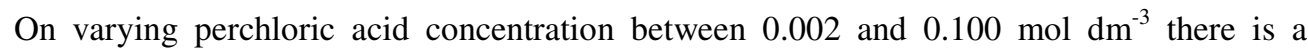
decrease in reaction rate (Table 3). The plot of log $\mathrm{k}$ versus $\log \left[\mathrm{H}^{+}\right]$(Figure 4) gave a straight line with positive intercept at $0.73\left(\mathrm{R}^{2}=0.98\right)$, suggesting that acid plays a complex role in the reaction system. The retardation by $\left[\mathrm{H}^{+}\right]$may be mainly attributed to the conversion of the more reactive neutral species of TrEG to less reactive protonated form. 


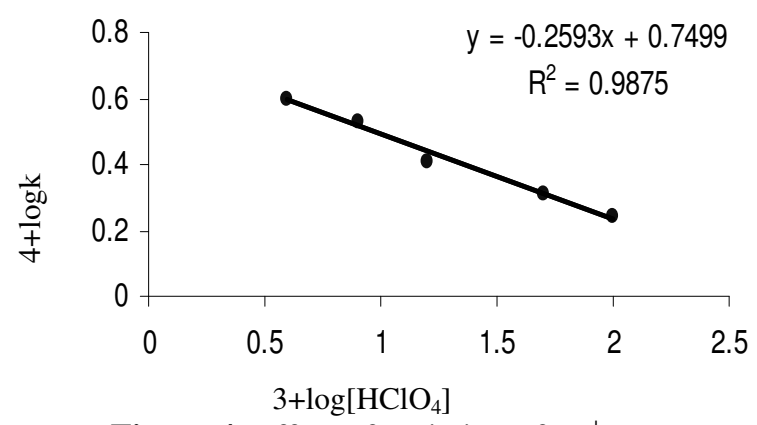

Figure 4. Effect of variation of $\left[\mathrm{H}^{+}\right]$

Table 3. Effect of variation hydrogen ion concentration

$[\mathrm{TrEG}]=0.08$ mole $\mathrm{dm}^{-3} ;[\mathrm{NCSA}]=0.01$ mole dm$^{-3}$ $\left[\mathrm{C}_{16} \mathrm{TAB}\right]=0.004$ mole $\mathrm{dm}^{-3} ;$ Temperature $323 \mathrm{~K}$

\begin{tabular}{cc}
\hline$\left[\mathrm{HClO}_{4}\right] / 10^{-2} \mathrm{~mol} \mathrm{dm}^{-3}$ & $\mathrm{k}^{*} / 10^{-4} \mathrm{~s}^{-1}$ \\
\hline 0.2 & 4.63 \\
0.4 & 3.98 \\
0.8 & 3.34 \\
1.6 & 2.35 \\
5.0 & 2.07 \\
10.0 & 1.77 \\
\hline$*$ Mean of duplicate experiments
\end{tabular}

Dependence of rate on $\left[C_{16} T A B\right]$

The addition of $\mathrm{C}_{16} \mathrm{TAB}$ in the reaction system catalyzed the reaction. As the reported ${ }^{18}$ critical miceller concentration of $\mathrm{C}_{16} \mathrm{TAB}$ is $9.2 \times 10^{-4}$ at $25^{\circ} \mathrm{C}$, the concentration of $\mathrm{C}_{16} \mathrm{TAB}$ varied from $2.0 \times 10^{-3}$ to $10.0 \times 10^{-3} \mathrm{~mol} \mathrm{dm}^{-3}$ and the rate of reaction increases (Table 4). The plot of $\mathrm{k}$ versus $\left[\mathrm{C}_{16} \mathrm{TAB}\right]$ (Figure 5) gives a straight line. Surfactants are tending to form micelles.

Table 4. Effect of $\mathrm{C}_{16} \mathrm{TAB}$ concentration variation

$$
\begin{array}{cc}
{[\mathrm{TrEG}]=0.08 \mathrm{~mole} \mathrm{dm}^{-3} ;} & {[\mathrm{NCSA}]=0.01 \text { mole dm}^{-3}} \\
{\left[\mathrm{HClO}_{4}\right]=0.05 \mathrm{~mole} \mathrm{dm}^{-3} ;} & \begin{array}{c}
\text { Temperature } 323 \mathrm{~K} \\
\hline\left[\mathrm{C}_{16} \mathrm{TAB}_{]} / 10^{-3} \mathrm{~mol} \mathrm{dm}^{-3}\right.
\end{array} \\
\hline 0.0 & \mathrm{k}^{*} / 10^{-4} \mathrm{~s}^{-1} \\
2.0 & 0.009 \\
4.0 & 1.34 \\
6.0 & 1.91 \\
8.0 & 2.44 \\
10.0 & 3.73 \\
\hline \text { * Mean of duplicate experiments } & 4.76 \\
\hline
\end{array}
$$

One of the important properties of miceller systems is their ability to affect the rates of chemical reactions. The reaction rate can either be accelerated or retarded, depending on chemical system, the type and concentration of surfactant and other factors such as $\mathrm{pH}$, ionic strength etc. The effect of surfactants on reaction kinetics is called miceller catalysis ${ }^{17}$. Micelles are formed due to assembling of amphiphilic molecules of surfactant above a certain concentration called critical miceller concentration ${ }^{18,19}$. Micelle catalysis of reaction in aqueous solutions is usually explained on the basis of a distribution of reactants between 
water and the miceller 'pseudo phase'. The micelles may provide a favorable orientation of the reactants by polarity gradients. In the present reaction, hydrophobic interaction is most likely to be operative due to relative larger hydrocarbon chains of the substrate ${ }^{20,21}$. This interactive localization of the reacting species in the relatively small volume of the micelles compared to the bulk solution leads to a large increase in the effective concentration and as a result the observed rate increased accordingly. The other most probable reason seems to be electrostatic attraction between polar TrEG and the micelle.

\section{Variation of ionic strength, dielectric constant and saccharin}

With the employed reactant concentrations, initial ionic strength of the reaction mixture was 0.064 . The effect of ionic strength has been studied by varying the concentration of neutral sodium perchlorate from 0.064 to $0.124-\mathrm{mol} \mathrm{dm}^{-3}$. It was found that there is no substantial change in the reaction rate on varying the ionic strength.

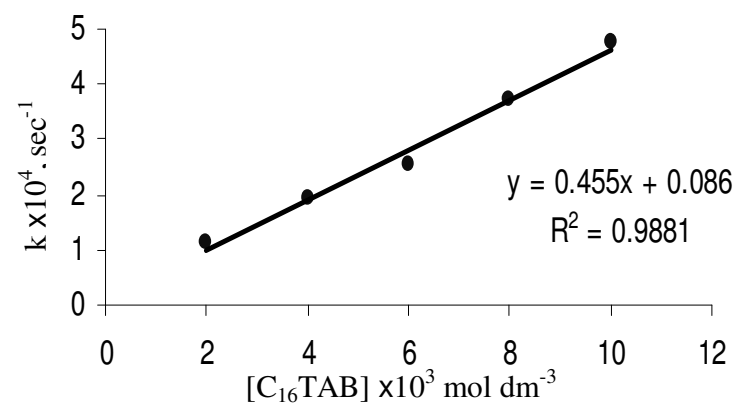

Figure 5. The plot of $\mathrm{k}$ versus $\left[\mathrm{C}_{16} \mathrm{TAB}\right]$

The small salt effect suggests the participation of neutral species in rate determining step i.e. the substrate molecule and $(\mathrm{HOCl})$. This assumption is further supported by observing the effect of change in dielectric constant of the reaction medium. The effect of dielectric constant in reaction medium was studied by adding acetic acid (20-60\%) in the reaction medium at constant concentrations of other reactants. The rate of reaction decreases by increasing the proportion of acetic acid in the solvent medium; this validates the involvement of neutral species in the rate-determining step. Addition of saccharin (one of the reaction products), from 0.0005 to $0.0025 \mathrm{~mol} \mathrm{dm}^{-3}$ at constant NCSA and TrEG concentration, decreases the rate of reaction. This conforms that $\mathrm{HOCl}$ is the main oxidizing species. The retardation of reaction rate on the addition of saccharin suggests a preequilibrium step that involves a process in which saccharin is one of the products. If this equilibrium is involved in the oxidation process the retardation should be an inverse function of saccharin concentration, which is borne out by observation that the inverse of the rate constant gives a linear plot $\left(\mathrm{R}^{2}=0.97\right)$ against [saccharin] (Figure 6). The addition of acrylonitrile to the reaction mixture had no effect, indicating the absence of free radical species during the reaction. This observation further supports the participation of neutral species in rate determining step, i.e. the substrate molecule and $\mathrm{HOCl}$.

\section{Effect of Temperature}

The reaction was studied at different temperatures. Rate constants at 318, 323, 328, 333 and $338 \mathrm{~K}$ were found to be $1.11 \times 10^{4} \mathrm{sec}^{-1}, 1.91 \times 10^{4} \mathrm{sec}^{-1} 2.65 \times 10^{4} \mathrm{sec}^{-1}, 6.43 \times 10^{4} \mathrm{sec}^{-1}$, and $7.00 \mathrm{k} \mathrm{x} 10^{4} \mathrm{sec}^{-1}$ respectively. From the linear Arrhenius plot of $\log \mathrm{k}$ Vs 1/T (Figure 7) activation parameters for overall reaction were evaluated $\mathrm{Ea}=93.45 \mathrm{KJ} \mathrm{mol}^{-1} \Delta \mathrm{H}^{*}=90.74$ $\mathrm{KJ} \mathrm{mol}^{-1}, \Delta \mathrm{G}^{*}=102.34 \mathrm{KJ} \mathrm{mol}^{-1}, \Delta \mathrm{S}^{*}=-27.51 \mathrm{JK} \mathrm{mol}^{-1}$ respectively. 


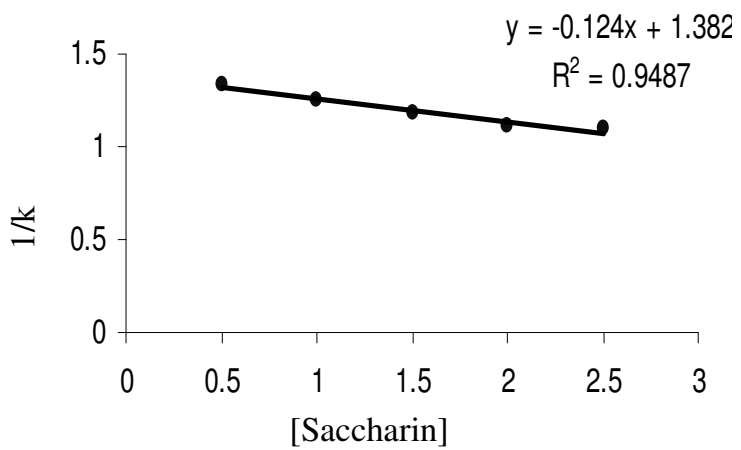

Figure 6. Effect of added saccharin

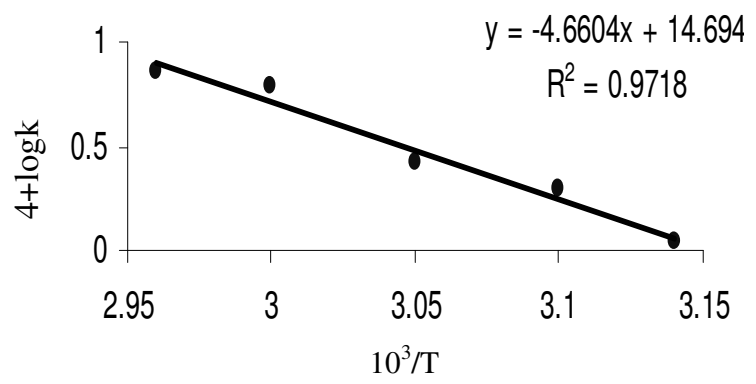

Mechanism

Figure 7. Arrhenius plot.

From the various relevant literatures ${ }^{22-26}$ the different probable steps involved in NCSA system may be summarized as follows:

$$
\begin{aligned}
& \mathrm{NCSA}+\mathrm{H}_{2} \mathrm{O} \rightarrow \mathrm{HOCl}+\text { Saccharin } \\
& \mathrm{HOCl}+\mathrm{H}^{+} \rightarrow \mathrm{H}_{2} \mathrm{O}^{+} \mathrm{Cl} \\
& \mathrm{NCSA}+\mathrm{H}^{+} \rightarrow \mathrm{NCSAH}^{+} \\
& \mathrm{NCSAH}+\mathrm{H}_{2} \mathrm{O} \rightarrow \mathrm{H}_{2} \mathrm{O}^{+} \mathrm{Cl}+\text { Saccharin }
\end{aligned}
$$

Therefore $\mathrm{HOCl}, \mathrm{H}_{2} \mathrm{O}^{+} \mathrm{Cl}$ and $\mathrm{NCSAH}^{+}$are the possible oxidizing species in acidic medium. The experimental observations indicate that in the present case, $\mathrm{HOCl}$ is the main oxidizing species. So the following mechanism has been proposed. The linear double reciprocal plot of $\mathrm{k}^{-1}$ versus $[\mathrm{TrEG}]^{-1}$ with positive intercept at $\mathrm{y}$-axis suggests the formation of the complex between substrate and the oxidant. Thus, the rate determining step proposed is-

$$
\begin{aligned}
& \mathrm{OHCH}_{2}-\mathrm{CH}_{2}-\mathrm{O}-\mathrm{CH}_{2}-\mathrm{CH}_{2}-\mathrm{O}-\mathrm{CH}_{2}-\mathrm{CH}_{2}-\mathrm{O}^{-} \mathrm{CH}_{2}-\mathrm{CH}_{2} \mathrm{OH}+\mathrm{HOCl} \stackrel{\text { Slow }}{\longrightarrow} \mathrm{X}_{1} \\
& \mathrm{X}_{1}+\mathrm{H}_{2} \mathrm{O} \stackrel{\text { Fast }}{\longrightarrow} \mathrm{OHCH}_{2}-\mathrm{CH}_{2}-\mathrm{O}-\mathrm{CH}_{2}-\mathrm{CH}_{2}-\mathrm{O}-\mathrm{CH}_{2}-\mathrm{CH}_{2}-\mathrm{O}-\mathrm{CH}_{2}-\mathrm{CHO}+2 \mathrm{H}_{2} \mathrm{O}+\mathrm{HCl}
\end{aligned}
$$

The small salt effect, the increase in reaction rate on increasing the dielectric constant and the linear reciprocal plot between $\mathrm{k}^{-1}$ versus $[\mathrm{TrEG}]^{-1}$ with positive intercept on the y-axis (Figure 8), support the equation (6). The complex thus formed will be rapidly decomposed into the products, in equation (7).

\section{$C_{16}$ TAB Catalyzed Mechanism}

The reaction between TrEG and $N$-chlorosaccharin in acidic medium is very slow. Addition of $\mathrm{C}_{16} \mathrm{TAB}$ catalyzed the reaction. The physical basis of miceller catalysis is the effect of the miceller environment on the rate-controlling step. The relative free energies of the reaction (s) 
and /or the transition state can be altered when reaction takes place in the miceller system instead of bulk water. This concept is reminiscent of catalysis by an enzyme and many initial studies of rates in miceller system focused on this possibility. A more important consideration is the localization of the reacting species in the relatively small volume of the micelle compared to bulk solution.

The following mechanism is proposed for the catalysis by $\mathrm{C}_{16} \mathrm{TAB}$ :

$$
\begin{aligned}
& \mathrm{nC}_{16} \mathrm{TAB} \rightarrow\left(\mathrm{C}_{16} \mathrm{TAB}\right)_{\mathrm{n}} \\
& \mathrm{OHCH}_{2}-\mathrm{CH}_{2}-\mathrm{O}-\mathrm{CH}_{2}-\mathrm{CH}_{2}-\mathrm{O}-\mathrm{CH}_{2}-\mathrm{CH}_{2}-\mathrm{O}-\mathrm{CH}_{2}-\mathrm{CH}_{2} \mathrm{OH}+\left(\mathrm{C}_{16} \mathrm{TAB}\right)_{\mathrm{n}} \rightarrow \\
& {\left[\mathrm{OHCH}_{2}-\mathrm{CH}_{2}-\mathrm{O}-\mathrm{CH}_{2}-\mathrm{CH}_{2}-\mathrm{O}-\mathrm{CH}_{2}-\mathrm{CH}_{2}-\mathrm{O}-\mathrm{CH}_{2}-\mathrm{CH}_{2} \mathrm{OH} \ldots\left(\mathrm{C}_{16} \mathrm{TAB}\right)_{\mathrm{n}}\right]} \\
& {\left[\mathrm{OHCH}_{2}-\mathrm{CH}_{2}-\mathrm{O}-\mathrm{CH}_{2}-\mathrm{CH}_{2}-\mathrm{O}-\mathrm{CH}_{2}-\mathrm{CH}_{2}-\mathrm{O}-\mathrm{CH}_{2}-\mathrm{CH}_{2} \mathrm{OH} .\left(\mathrm{C}_{16} \mathrm{TAB}\right)_{\mathrm{n}}\right]+\mathrm{HOCl} \rightarrow \mathrm{X}_{1}} \\
& \mathrm{X}_{1}+\mathrm{H}_{2} \mathrm{O} \rightarrow \mathrm{OHCH}_{2}-\mathrm{CH}_{2}-\mathrm{O}-\mathrm{CH}_{2}-\mathrm{CH}_{2}-\mathrm{O}-\mathrm{CH}_{2}-\mathrm{CH}_{2}-\mathrm{O}-\mathrm{CH}_{2}-\mathrm{CHO}+2 \mathrm{H}_{2} \mathrm{O}+\mathrm{HCl}
\end{aligned}
$$

Rate law

The rate equation for the catalyzed reaction between TrEG and NCSA can be represented by the equation -

$$
-\mathrm{d}[\mathrm{NCSA}] / \mathrm{dt}=\mathrm{k}_{0}[\mathrm{TrEG}]^{1}[\mathrm{NCSA}]
$$

when $[\mathrm{NCSA}]$ in excess above equation (12) reduces to

$$
\mathrm{r}=\mathrm{k}_{0}^{\prime}[\mathrm{TrEG}]^{1}
$$

Where the rate constant for catalyzed reaction, $\mathrm{k}_{0}^{\prime}=\mathrm{k}_{0}$ [NCSA]. The plot between reaction rate and $\sqrt{[\mathrm{TrEG}]}$ (Figure 8) gave a linear plot that validates equation (13). In the presence of the catalyst, the oxidation proceeds through catalyzed pathways. Therefore, the following represents the rate of depletion of NCSA in presence of catalyst under excess [TrEG] and acid concentrations:

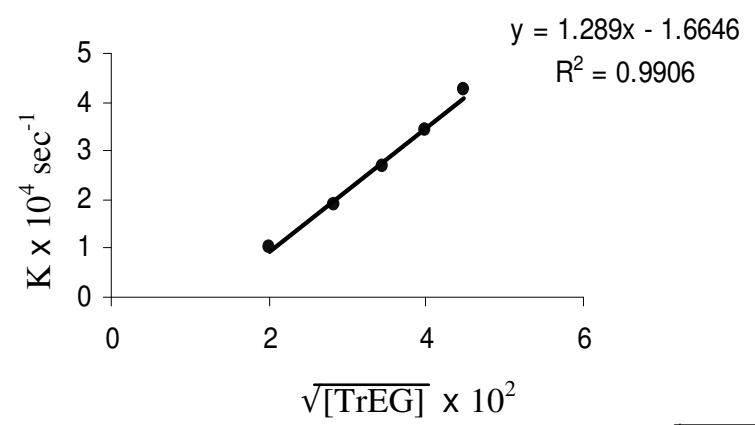

Figure 8 . The plot between reaction rate and $\sqrt{[\mathrm{TrEG}]}$

Here $\mathrm{k}_{\mathrm{c}}^{\prime}=\mathrm{k}_{\mathrm{c}}[\mathrm{NCSA}]$

$$
-\mathrm{d}[\mathrm{NCSA}] / \mathrm{dt}=\left\{\mathrm{k}_{0}^{\prime}+\mathrm{k}_{\mathrm{c}}^{\prime}\left[\mathrm{C}_{16} \mathrm{TAB}\right]\right\}[\mathrm{NCSA}]
$$

$$
=\mathrm{K}^{\prime \prime}[\mathrm{NCSA}] \text { Where } \mathrm{k}^{\prime \prime}=\left\{\mathrm{k}_{0}^{\prime}+\mathrm{k}_{\mathrm{c}}^{\prime}\left[\mathrm{C}_{16} \mathrm{TAB}\right]\right\}
$$

Equation (15) holds good, when a plot of observed rate constant in presence of the catalyst, $\mathrm{k}$ versus $\left[\mathrm{C}_{16} \mathrm{TAB}\right]$ is linear (c.f. Figure 5).

\section{References}

1. Konyukhov V Yu, Chernaa I V and Naumov V A, Kinet. Catal. (Transl. of Kinet. Katal.), 1997, 38, 81.

2. Benjankiwar R S, Basu A and Cementi M, J. Environ. Sci(China), 2004, 16(5), 851-855. 
3. Mantzavinos D, Hellenbrand R, Livingston A G and Metcalfe I S, Applied Catalysis B: Environmental, 1996, 11(1), 99-119.

$4 \quad$ Singh R A and Singh R S, Oxid. Commun., 1997, 20, 248.

5. Manibala Tandon P K and Krishna B, Z. Phys. Chem(Leipzig), 1985, 266, 1153.

$6 \quad$ Singh R N, Singh R K and Singh H S, J. Chem. Res.(S), 1977, 10, 249.

7. Goswami G, Kothari S and Banerji K K, Proc. Indian Acad. Sci.,(Chem. Sci), 2001, 113(1), 43-54.

8. $\quad$ Gosain J and Sharma P K, Proc. Indian Acad. Sci., (Chem. Sci.), 2003,115(2), 135-145 .

9. $\quad$ Behari K, Shrivastava R and Veena, J Chem Res, 2001, 2001(5),182-184.

10. Svetlakov N V, Nikitin V G and Orekhova A O, Russian J. Org Chem, 2002, 38(5), 753.

11. Jin-Huan S, Shu-Ying H, Fei-Wang, Shi-Gang S and Han-Wen S, J. Chem Res, 2004, 2004(10), 674.

12 Zabicky J, The Chemistry of Amides, Interscience Publishers, John Wiley \& Sons, 1970, 374.

13 Chattaway F D, J. Chem. Soc., 1905, 87, 1884.

14 Bacchawat J M, Indian J. Chem., 1971, 9, 1335.

15 Vijay Mohan K, Raghunath Rao P and Sundram E V, Proc. Natl. Acad. Sci. India, 1988, 58A, 37.

16 Singh G, Bansal S C, Gupta D, Sharma I, Khandelwal L and Sharma P D, Indian J. Chem., 2001, 40A, 714.

17 Fendler J H, Membrane Mimetic Chemistry, John Wiley New York, 1982, Chapter 2-6.

18 Wennerstrom H and Lindman B, Phys. Rev., 1979, 52, 1.

19 Mukherjee P, Adv Coll. Interface Sci, 1967, 1, 241.

20 Fisher L R and Oakenfull D G, Quart. Rev. Chem. Soc., 1977, 6, 25.

Bacchawat J M, Koul A K, Prasad B and Ramegowda N S, Indian J. Chem., 1973, 11, 609. Khan M U, Tiwari R K, Verma J K and Gupta H D, ibid, 1997, 20(1), 117-123.

Khan M U, Sharma V K, Sharma K and Dwivedi H P, Oxid. Commun., 1991,14(1), 60-65. Khan M U, Verma J K, Singh V R and Dwivedi H P, ibid, 1993, 16(3), 235-239. Khan M U, Nigam S K, Nigam A, Verma J K and Chauhan R P S, ibid, 1995,18(3), 304-311.

26 Singh V P, Khan M U, Chauhan D B S and Verma J K, ibid, 1997, 20(1), 124-131. Gupta C, Mishra S K and Sharma P D, Trans. Met. Chem., 1994, 19, 6569.

28 Menghani G D and Bakare G V, Curr. Sci., 1968, 37, 641.

29 Bhagwat V W, Tiwari J, Choube A and Pare B, J. Serb. Chem. Soc., 2003, 68(7), 535-542.

30 Kawai F, Kimura T, Fukaya M, Tani Y, Ogata K, Ueno T and Fukami H, Appl. Environ. Micro., 1978, 35(4), 679-684. 


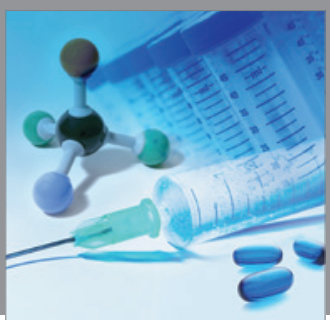

International Journal of

Medicinal Chemistry

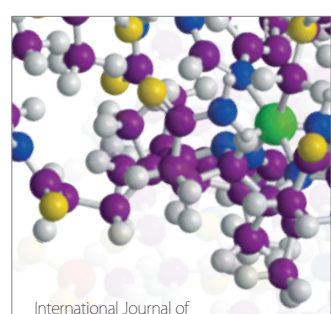

Carbohydrate Chemistry

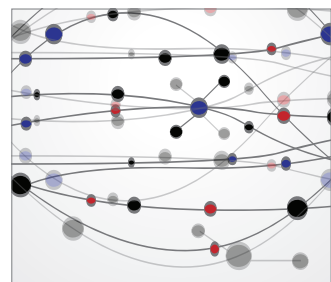

The Scientific World Journal
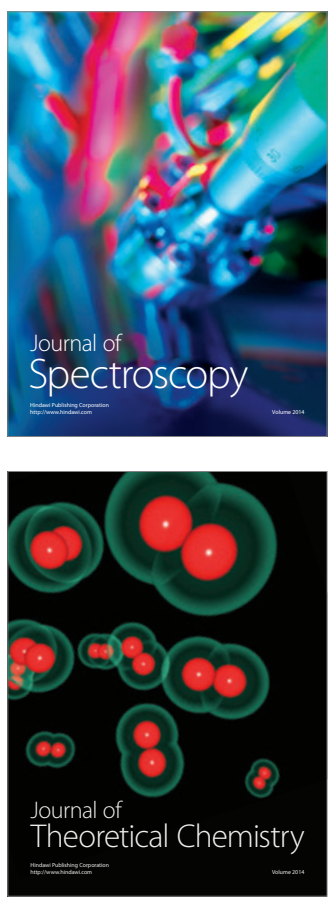
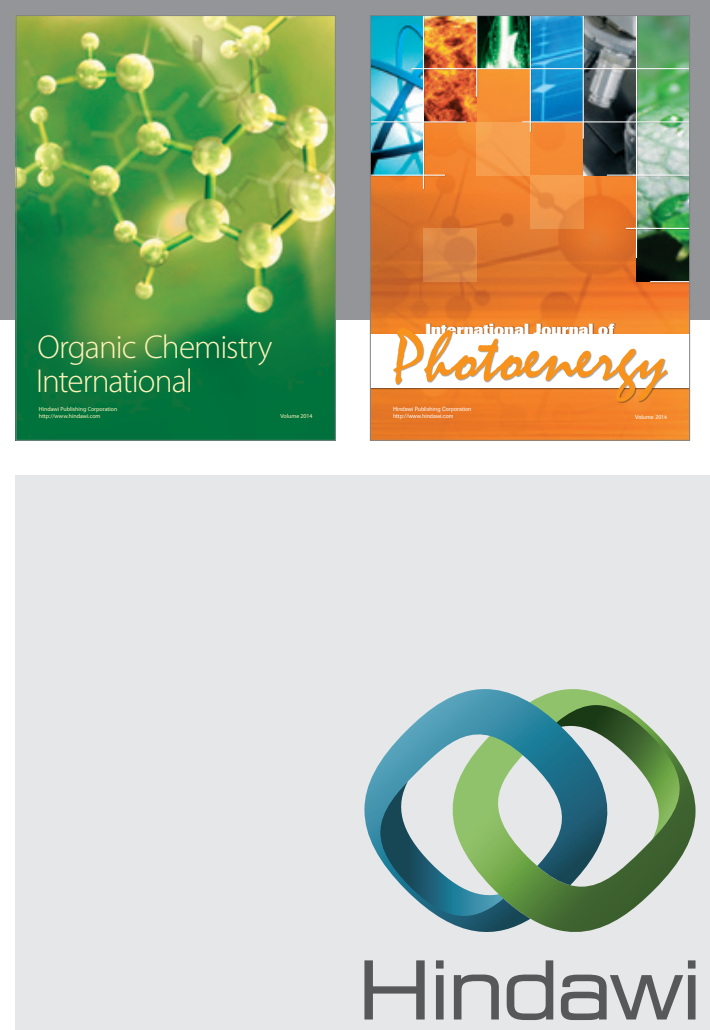

Submit your manuscripts at

http://www.hindawi.com
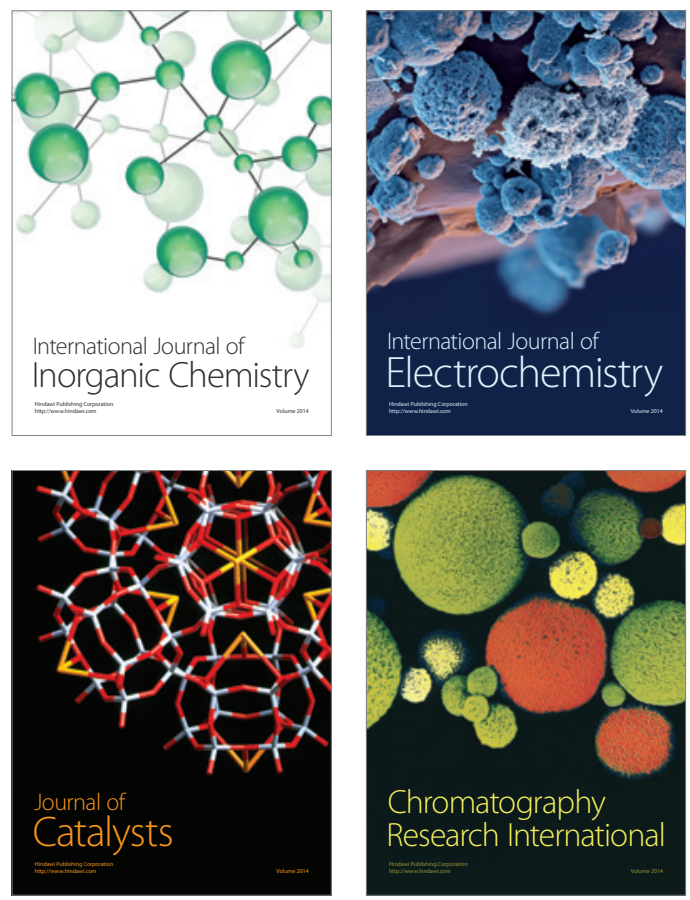
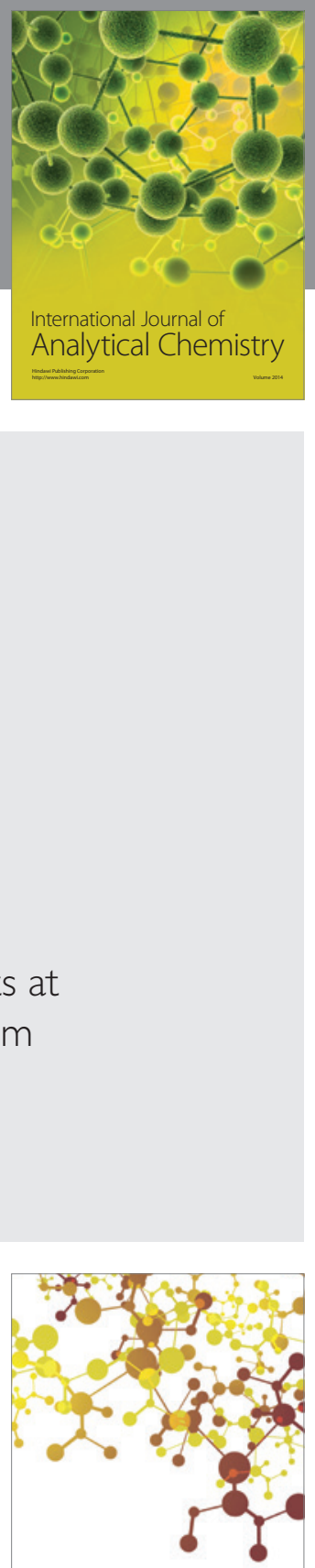

Journal of

Applied Chemistry
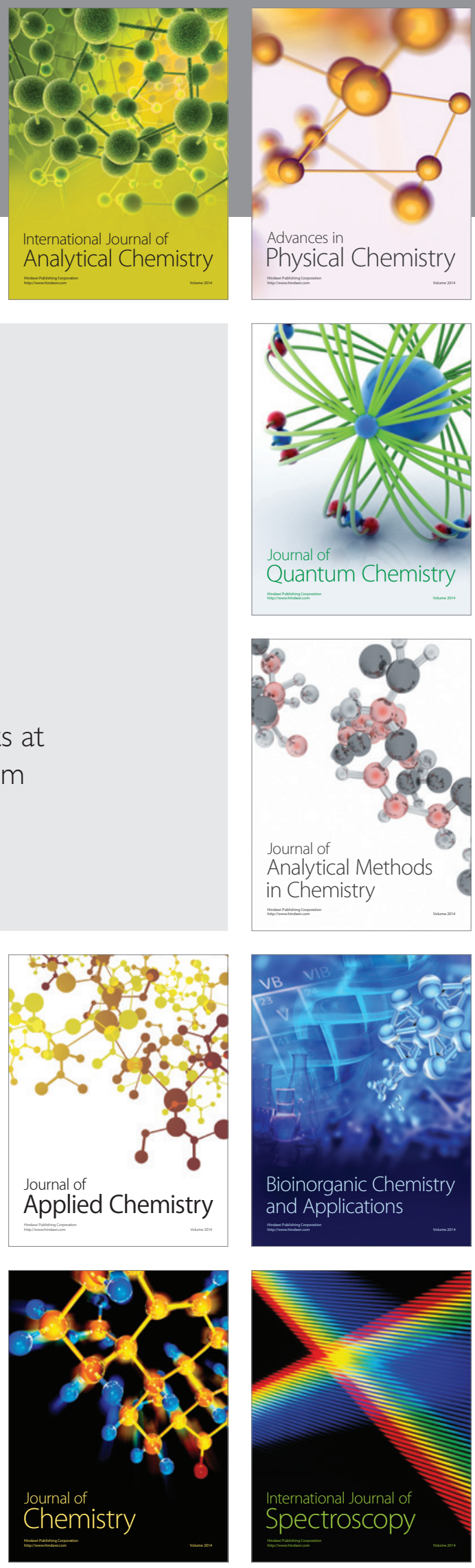